\title{
THE RELATIONSHIP BETWEEN LINGUISTICS AND OTHER SCIENCES IN INDIA*
}

(published in: History of the Language Sciences / Geschichte der Sprachwissenschaften / Histoire des sciences du langage, vol. I. Ed. Sylvain Auroux, E. F. K. Koerner, Hans-Josef Niederehe, Kees Versteegh. Berlin - New York: Walter de Gruyter. 2000. Pp. 166-173)

\section{§1. Introduction.}

Classical India has various language sciences. Three of the six traditional auxiliary sciences of the Veda (vedāinga) — phonetics (śikṣâa), etymological explanation (nirukta), grammar (vyākarana) — deal with language. The various Prātiśākhyas — which precede the surviving treatises of sikșa, and are its authentic representatives according to Renou ${ }^{1}$ — deal with Vedic phonetics. Vedic hermeneutics (mīmāmsāâ), too, can be looked upon as a language science, and so can certain developments of Indian philosophical thought. But grammar was most widely studied. Grammar, according to the grammarian Patañjali (2nd cent. B.C.E.), is the most important among the six auxiliary sciences. We will therefore confine our attention to grammar (vyākarana) - and in particular to the oldest surviving, and most important, text of this genre: Pạnini's Aṣtāâdhyāȳ̄ — in its relationship to other sciences.

Grammar did not interact with mathematics and the natural sciences (astronomy and medicine), or at least not strongly. ${ }^{2}$ The suggestion that Pạnini's "linguistic zero" caused or influenced the introduction of zero in mathematics has no evidence to support it. ${ }^{3}$ Note however that the expression "natural sciences" is apt to be misleading in the classical Indian context: physics and part of chemistry have their closest parallels in what are commonly referred to as schools of Indian philosophy. Other Indian sciences, often without parallel in the modern world, include: etymological explanation (nirukta); ritual science ( $k a l p a)$, like etymological explanation one of the auxiliary sciences of the Veda; ${ }^{4}$ Vedic hermeneutics (mīmāmsāa); poetic science (kāvyaśāstra).

Two kinds of relationship between grammar and other sciences will be primarily considered: (1) another science influenced grammar, and (2) grammar influenced

\footnotetext{
* History of the Language Sciences / Geschichte der Sprachwissenschaften / Histoire des sciences du langage, vol. I. Ed. Sylvain Auroux, E.F.K. Koerner, Hans-Josef Niederehe, Kees Versteegh. Berlin New York: Walter de Gruyter. 2000. Pp. 166-173. I thank Jan E.M. Houben for useful criticism.

${ }^{1}$ Renou, 1963: 167.

${ }^{2}$ Pierre-Sylvain Filliozat (1995) does not succeed in proving the reverse.

${ }^{3}$ See Ruegg, 1978.

${ }^{4}$ Frits Staal (1982; 1989: 349 f.) argues for the scientific status of the "science of ritual".
} 
another science. In reality the interaction was often less unidirectional, and in some cases the bi-directional nature of the interaction will be mentioned. For the earliest period forms of "knowledge" that had not yet been systematised into "sciences" will have to be taken into consideration.

\section{§2. The origin of grammar.}

Grammar arose in circles connected with Vedic ritual. Does it preserve traces of this early connection? The classical publication is Louis Renou's "Les connexions entre le rituel et la grammaire" (1942), which is more circumspect in its formulations than are some more recent publications. It draws attention to various parallels between the two sciences, such as the shared aphoristic (sūtra) style, ${ }^{5}$ the presence in both of general interpretative rules (paribhāsa $\bar{a}$ ) — sometimes similar ones —, and the elements of vocabulary which they have in common. However, as Renou himself admits, these parallels do only in certain cases allow us [167] to conclude that ritual influenced grammar rather than vice-versa. The influence considered is moreover limited to details, and hardly justifies the conclusion that grammar in India owes its existence, or its specific nature, to ritual science.

One of the less doubtful antecedents of grammar is the early preoccupation with the correct preservation of Vedic texts. The Rgveda, for example, has been preserved in many different forms of recitation, two of which are of particular interest here: the padapātha "word for word recitation" and the samhitāpātha "continuous recitation". Neither of these two (nor indeed any of the other ones) represents the original form of the Rgveda. The padapattha separates the words (and certain components of words) of the text, the samhitāpātha joins them in sandhi (called samhitā in Vedic literature and Pānini's grammar). The padapātha of the Rgveda is older than Pānini (he refers to it), its saṃhitāpātha appears to be younger (it applies rules of sandhi which destroy the original meter, where Pānini's rules preserve it). ${ }^{6}$ The question as to how the samhitāpātha is formed on the basis of the padapātha is a central concern of the Prātiśākhyas, and early reflections of this nature contributed no doubt to the creation of grammar. Reflections about details of sandhi also gave rise to "mystical" speculations. ${ }^{7}$

Other aspects of grammar arose for different reasons. The Sanskrit term for grammar, vyākarana, provides a clue. This means literally "separation, distinction", and this is often taken to refer to the fact that grammar distinguishes roots, suffixes, and

\footnotetext{
${ }^{5}$ See also Renou, 1963: $175 \mathrm{f}$.

${ }_{7}^{6}$ See Bronkhorst, 1981; 1991: $75 \mathrm{f}$.

${ }^{7}$ E.g. Aitareya Āranyaka 3.2.6; Śāṅkhāyana Āranyaka 8.11; Ṛgveda Prātiśākhya 1.2 f.
} 
prefixes. ${ }^{8}$ Paul Thieme (1982: 11 [1178]) has however rightly pointed out that Pānini's grammar does not analyse. This grammar rather presupposes constituent functional elements and shows how they are to be combined. Thieme proposes "[word-]formation" for vyākarana, which is not convincing. He overlooks the fact that grammar, though not separating the constituent elements of words, does separate words and their meanings. This, at any rate, is a theme that recurs a number of times in Vedic literature, frequently in passages that use precisely the verb $v y-\bar{a}-k r-$, from which vyākarana is derived. These passages speak about the separation of name (nāman) and shape (rūpa). Bṛhadāranyaka Upanișad 1.4.7 - to cite but one example - states: "All this was unseparated (indistinguishable) (avyākrta) [in the beginning of creation]. Then it became separated (distinguished) (vyākriyata) by name and shape [so it became possible to say]: 'This particular one is of the name NN and of such and such a shape.' Therefore, even to-day distinction is made (vyākriyate) by name and shape: 'This particular one is of the name NN [and] of such and such a shape'." (tr. Thieme). Passages like this could be looked upon as the mythological counterpart of an important feature of Pānini's grammar (and for the grammars that existed before him, we may assume), which shows how the now separated meanings and word-forms are related to each other. ${ }^{9}$ Early thinkers about language, we are led to believe, were interested in the details of the separation of words and things reported in their mythology.

\section{§3. Interaction with 'etymological explanation' (nirukta).}

The background of another aspect of grammar is elucidated by its relationship with the Vedic auxiliary science of 'etymological explanation' (nirukta). This science is presented in a systematised form in Yāska's work called, precisely, Nirukta - a text which may belong to the period between Pānini (after 350 B.C.E.) and Patañjali (around 150 B.C.E.) -,${ }^{10}$ but the practice of etymologizing is extremely common in the earlier Vedic Brāhmanas. These Vedic etymologies do not concern the histories of words and cannot, therefore, be compared with modern linguistic etymologies — , but have altogether different aims. As a rule they reveal hidden connections with the mythological realm, which can be multiple. (In practice this means that one word can have several different 'etymologies'.) Knowing them brings advantages, as does knowing other hidden truths.

\footnotetext{
${ }^{8}$ So e.g. Scharfe, 1977: 83.

${ }^{9}$ Bronkhorst, 1980.

${ }^{10}$ For the date of Pānini, see Hinüber, 1989: 34; Falk, 1993: 304. For Patañjali's date, see Cardona, 1976: $263 \mathrm{f}$.
} 
The 'etymologies' in Yāska's Nirukta are their secularised descendants. 'Etymologizing' has here become a method for finding the meaning of unknown words. Two presuppositions underlie it: (1) The meaning of a word (primarily noun or adjective) is the result of a combination of the meanings of its parts. (2) The meanings of those parts are not assigned to them by convention, they intimately belong to them. ${ }^{11}$ [168]

These same presuppositions appear to underlie Pānini's grammar. Here, as we have seen $(\S 2)$, constituent functional elements of words are combined, and the meaning of the resulting word is considered to be the combination of the meanings attaching to (or, in view of the above: separated from) those elements. The complementary character of grammar and 'etymological explanation' is confirmed by Yāska, who describes 'etymological explanation' in his Nirukta (1.15) as the 'complement of grammar'. But whereas 'etymological explanation' concentrates on cases that resist analysis, grammar normally confines itself to words the relationship of which with other words seems obvious and regular. ${ }^{12}$ The analytical aspect of grammar, the search for the constituents of words, we must conclude, derives from the preoccupation with 'etymological' connections characteristic of much of Vedic literature.

The interaction of grammar with 'etymological explanation' was not unidirectional. Yāska refers in his Nirukta to grammar, and it seems likely that Pāṇini's Așțādhyāyī was known to him. ${ }^{13}$ He justifies the procedures of 'etymological explanation' - such as ignoring, modifying, or inverting sounds - by pointing at similar practices in grammar (Nirukta 2.1). It appears that 'etymological explanation', when it tried to attain the status of a science besides grammar, drew inspiration from the latter.

§4. Influence from philosophy.

Pānini's grammar shows the traces of Vedic religious thought, as we have seen. Philosophical systematic thought did not exist in India at his time, as far as we can tell. Influence from that side can be discerned in the two earliest surviving commentaries, Kātyāyana's vārttikas and Patañjali's Mahābhāṣya, especially the latter. A systematised world view was being developed at that time — for the first time in India, it seems - in the Buddhist school called Sarvāstivāda, which was deeply interested in questions of

\footnotetext{
${ }^{11}$ Bronkhorst, 1981a.

${ }^{12}$ Bronkhorst, 1984.

${ }^{13}$ Thieme, 1935; Bronkhorst, 1984: 8 f.
} 
existence. For reasons connected with the historical development of Buddhism, a list of so-called dharmas came to be looked upon as the complete list of all there is. These dharmas were considered to be the ultimate constituents of persons and things. The persons and things themselves, being collections of dharmas, were not believed to really exist. Sarvāstivāda introduced a number of dharmas whose function it was to solve certain theoretical difficulties. Most of these theoretically useful dharmas were given a place in the category of dharmas called "separated from mind" (cittaviprayukta). Three of these dharmas are of particular interest. They are padakāya, nāmakāya and vyañjanakāya. This could be translated as 'sentence', 'word' and 'phoneme' respectively, where it is to be kept in mind that these linguistic units are here conceived of as dharmas, i.e., as partless, ultimate, really existing entities. It seems likely that originally — i.e., around the time of Patañjali — only two of these three dharmas were recognised, the word and the phoneme.

Possibly influenced by Sarvāstivāda, Patañjali introduces two new notions into grammatical discourse, adapting them to their new Brahmanical environment: the word and the phoneme as single, independent entities. Both are eternal, contrasting in this respect with the momentary Buddhist dharmas. In connection with the phoneme Patañjali introduces a term which will play an important role in later linguistic speculation: sphoța. But, as in Sarvāstivāda, the word and the phoneme are unitary, indivisible entities, different from the sound that expresses them. ${ }^{14}$ And where for Pānini morphemes were the basic units of language, Patañjali assigns them a derived meaning at best. ${ }^{15}$

§5. Language and philosophy.

The role of grammar in Indian thought has regularly been emphasised. Louis Renou, for example, made the often cited statement "To adhere to Indian thought means first of all to think like a grammarian" (Adhérer à la pensée indienne, c'est d'abord penser en grammairien; Renou, 1953: 86); and again: "Indian thought has as substructure reasonings of a grammatical nature" (La pensée indienne a pour substructure des raisonnements d'ordre grammatical; Renou, 1942: 164). Frits Staal, following D.H.H. Ingalls (1954), has made the claim that Pānini's grammatical method is characteristic of much of Indian philosophy, just as Euclid's mathematical method is characteristic of much of Western philosophy (Staal, 1960; 1963; 1965). This is

\footnotetext{
${ }^{14}$ Bronkhorst, 1987.

${ }^{15}$ Bronkhorst, forthcoming a.
} 
supposed to explain that scientific developments have taken different directions in India and the West. Bimal Krishna Matilal refers to the role of grammar in Indian philosophy, e.g., in the title of his book [169] Epistemology, Logic, and Grammar in Indian Philosophical Analysis (1971).

When it comes to substantiating these claims, one is disappointed. It is true that systematic abbreviations (a characteristic of Pānini's grammar) occur in mathematics, astronomy, and in other grammars; that the simplicity criterion and the algebraic sütra style (both also typical of Pānini's grammar, but perhaps first used in ritual science) are used in many philosophical works. It is also true that grammar was part of the curriculum of every educated Indian, so that grammatical discussions are to be found in practically all commentaries, whatever the nature of the text they comment upon, and elsewhere. ${ }^{16}$ But does this touch the heart of the matter? Does this interest in grammar go beyond the correct formation of words and sentences, and affect the contents of the treatises concerned? There are some, but not so many cases where grammatical analysis is used to reach a philosophical conclusion. ${ }^{17}$ The situation is complicated by the fact that many Indian authors looked upon the Sanskrit language as providing preferential access to reality, quite independently of any considerations of grammar. Something must be said about this.

Two phases are to be distinguished. During the first one language came to be considered - partly no doubt under Buddhist influence — as reflecting — or even creating / organising - phenomenal reality. Such a position has philosophical consequences, which were worked out in greatest detail in the Brahmanical system of philosophy called Vaiśeșika. The conviction that there is a direct correspondence between words and things might be called an axiom of this system. It justifies the ontological conclusions based on verbal usage common in the writings of this school. ${ }^{18}$ But the influence of grammar on this school remains small. One may suspect such influence in its three main categories substance (dravya), quality (guna) and movement (karman), which correspond to nouns, adjectives and verbs respectively. But did the Vaiśeșikas need grammar in order to arrive at this division of words? The triple division into nouns, adjectives and verbs is not fundamental in Pānini's grammar.

The second phase is characterised by what has been called the "correspondence principle' ${ }^{19}$ which can approximately be formulated as follows: "the words of a statement correspond, one by one, to the things that constitute the situation described by that statement". The principle is plausible in the case of many, perhaps most,

\footnotetext{
${ }^{16}$ Filliozat, 1988: 19 ff.

${ }^{17}$ For some examples, see Torella, 1987.

${ }^{18}$ Bronkhorst, 1992; 1996.

${ }^{19}$ Bronkhorst, 1996a; forthcoming.
} 
statements, but leads to serious difficulties in the case of certain others. Statements of the form "he makes a pot" become problematic, because they do not describe a situation that contains a pot; the pot is still being made. These and related difficulties have been extensively discussed in Indian philosophical literature, and various solutions have been proposed and maintained by different authors and schools. Indeed, there are reasons to think that these discussions have led to several fundamental philosophical positions (such as the satkāryavāda, and the theory of denotation of certain schools), which are therefore based on certain views about language, not on grammar.

The correspondence principle is visible, perhaps for the first time, in a number of the contradictions presented by the Buddhist thinker Nāgārjuna in his important Mūlamadhyamakakārikā (2nd cent. C.E.?). Since some of these have been claimed to be based on grammar, they deserve some attention. Nāgārjuna claims that the statement "[The road] that is being travelled is being travelled" (gamyamānam gamyate) implies that there must be two actions of travelling in the situation described. This is a direct consequence of the correspondence principle, given that the root gam "to travel" is used twice over in this statement. It is also a paradox, given that the statement does not describe a situation where there are two actions of travelling. A following verse adds that if there are two actions of travelling, there must be two travellers, another conclusion that is in contradiction with the intention of the initial statement.

These arguments can be satisfactorily explained with the help of the correspondence principle. K. Bhattacharya does not agree, and has argued in a number of articles that the argument of the second verse considered ("if there are two actions of travelling, there must be two travellers") is based on grammar. ${ }^{20}$ It is grammar which maintains that an action resides either in an agent or in an object, and that the activity of travelling, more in particular, resides in its agent. This is true, but grammar does not specify that two actions cannot reside in one and the same agent. This is Nāgārjuna's own [170] conclusion. The link between his argument and grammar is therefore far less obvious than it is claimed to be. Indeed, the only possible influence from grammar in these arguments is that here, exceptionally, the correspondence principle is applied to verbal roots rather than to whole words.

\section{§6. Bhartrhari.}

We turn to Bhartrhari (5th cent. C.E.), the "philosopher of grammar". To what extent is his thought determined by grammar? We will not discuss the numerous

\footnotetext{
${ }^{20}$ Most recently Bhattacharya, 1995.
} 
passages where Bhartrhari deals with grammatical issues, but try to determine what influence grammar has exerted on his philosophy as a whole.

This philosophy as a whole concerns the nature of reality, in which Bhartrhari, contrary to the Buddhists, recognises the existence of composite objects. Or rather, composite objects are not really composite, they are indivisible entities that exist besides 'their' parts. More precisely again, the more encompassing a thing is, the more it is real. Highest reality, for Bhartrhari, is the totality of all there is, has been, and will be. The words of language divide this reality into (not really existing) parts.

So far Bhartrhari's philosophy is an interesting adaptation of the ideas described above: the objects of phenomenal reality correspond to the words of language. New is that these objects are considered to be less real than their totality. This way Bhartrhari could do justice to some traditional Brahmanical points of view, which looked upon the absolute as being the totality of all there is. Influence from grammar is not obvious here.

It seems clear nevertheless that grammar has contributed to this vision of reality. Consider first that Bhartrhari applies a similar reasoning to language: words are more real than the constituent morphemes (mainly stems and suffixes), sentences more real than the words they are made up of. More exactly, words are independent entities that are not constituted of morphemes, and sentences are not made up of words. It is only through artificial analysis of words that morphemes are invented by grammarians, and words on the basis of sentences.

It is clear that Bharțhari draws here inspiration from Patañjali's Mahābhāsya which, perhaps under the influence of Sarvāstivāda, had given ontological priority to words over stems and suffixes (see above). But Bhartrhari goes further and establishes an ontological hierarchy: words are more real than their morphemes, sentences more real than their words, and the Veda as a whole more real than its sentences. Patañjali's argument concerning the higher ontological status of words with regard to their stems and suffixes, now extended, allows in this way to climb the ontological ladder, so as to arrive at the highest insight, which is beyond words, and which concerns undivided reality. This insight brings about liberation, and in this way grammar is "the door to liberation", as Bhartṛhari puts it. ${ }^{21}$ Grammar has thus obtained an own philosophy, including an (in the Indian context important) liberating insight. But this philosophy is not based on the analysis of language implicit in Pānini's grammar, but quite on the contrary on the understanding that this analysis is not ultimately "real".

Bhartrhari is especially remembered for his link with the sphota, which in his case is primarily the indivisible word, different from the manifesting sounds. Later thinkers, both inside and outside the grammatical tradition, discuss and elaborate this

${ }^{21}$ This has been argued in Bronkhorst, 1996b; cp. Bronkhorst, 1992a. 
concept. Modern scholars — foremost among them John Brough (1951) — see in the sphota a concept of general linguistics, "simply the linguistic sign in its aspect of meaning-bearer (Bedeutungsträger)". In so doing they overlook the philosophical and ontological dimension of this concept, predominant in its original context. ${ }^{22}$

\section{$\S 7$. Understanding the meaning of a sentence.}

There is an area of thought where Pānini's analysis of the Sanskrit language has exerted a clear and unmistakable influence. It is the attempted description of the knowledge which a listener derives from hearing a sentence, the so-called verbal cognition (śâbdabodha), which came to occupy an important place in the three schools of thought called Mīmāmsāā (Vedic hermeneutics), Navya-Nyāya (the New Logic), and Vyākarana (grammar as a school of philosophy). ${ }^{23}$

The self-imposed task of Mīmāmssā was to interpret Vedic sentences. Its thinkers had come to think that injunctions are the crucial parts of Vedic texts. These injunctions do not express the intention of their author, for they have none (and nor do any other Vedic sentences), this because the Veda was believed to have no beginning in time. How, then, do Vedic injunctions enjoin? Reflections of this kind led the Mìmāmsakas to interpret, and paraphrase, the injunctions in ways that suited their purposes. ${ }^{24}$ Such paraphrases are already found in Śabara's Mīmāmsā Bhāṣya (5th cent.?), but a connection with the Pāninian analysis of words makes its appearance in a commentary on this work, Kumārila's Tantravārttika (7th cent.). This connection remained however incomplete, as can be seen from the following example. Sabara paraphrases the injunction svargakāmo yajeta "he who wishes to attain heaven should sacrifice" as yāgena svargam bhāvayet "by means of the sacrifice he should effect [the attainment of] heaven", which deviates rather profoundly from the Pāninian assignment of meanings. ${ }^{25}$ Kumārila, presenting the position of the system (śāstra), assigns the general meaning "productive operation" (bhāvanāa) to the verbal ending ( $t a$ in the case of yajeta). This deviates from the meanings assigned to the verbal ending by Pānini (primarily 'agent'), but takes the latter's formal analysis of the verb for granted. Pānini's formal analysis of the remainder of the sentence, on the other hand, does not play a role in Kumārila's discussions. It gains in importance in some of the subsequent refinements introduced in

\footnotetext{
${ }^{22}$ Bronkhorst, 1991a.

${ }^{23}$ For a general presentation, see Rao, 1969: esp. ch. I; Matilal, 1988; 1990: 53 f.; Coward and Kunjunni Raja, 1990.

${ }^{24}$ See Frauwallner, 1938.

${ }^{25}$ Śabara on MìS 2.1.1.
} 
the school. ${ }^{26}$ The constituent elements of a statement like rāmah odanam pacati "Rāma cooks rice" - rāma $+s$ - anna $+a m-p a c+t i-$ give rise to a paraphrase which gives each element its due, and which has the following (simplified) form: "The productive operation (bhāvanāa, meaning of $t i$ ) happening at present, which is done through the instrumentality of cooking that has rice as its object goal, and this efficient force is qualified by Rāma as its agent."

The Mīmāmsā points of view were subsequently taken into consideration, but combated, by Gañgeśa, a key figure of Navya-Nyāya (14th cent.). ${ }^{27} \mathrm{He}$ and his followers, too, present a paraphrase of verbal cognition which remains close to the Pāninian analysis of the sentence. Indeed, the reality of Pạninian morphemes is so much taken for granted by this school, that they refer to them as 'words' (pada). The main qualificand here is not the meaning of the verbal ending (as with the Mīmāmsakas), but that of the word with the nominative ending. The meaning of the sentence rāmah pacati "Rāma cooks" is here approximately paraphrased as: "Rāma who is qualified by the effort that is conducive to cooking." The verbal ending is given the meaning 'effort', which is, again, different from Pānini's meaning 'agent'.

Only the grammarians maintain the Pạninian meaning 'agent' for the (active) verbal ending. Following Bhartrhari, ${ }^{28}$ they look upon the meaning of the verbal root as the main qualificand. Kaunda Bhatța (17th cent.) — an important representative of this school - assigns the meaning 'activity conducive to the result' to verbal roots; the substratum of the activity is the agent, the substratum of the result the object. The sentence "Rāma cooks rice" (rāmah odanam pacati) is therefore to be paraphrased, in a simplified manner, as: "Present activity whose substratum is Rāma, which is conducive to the softening whose substratum is rice."29

In all these reflections and debates Pānini's analysis of the Sanskrit language is used as point of departure, even though the meanings assigned by him to the morphemes are only fully accepted by the grammatical philosophers.

\section{$\S 8$. Conclusion.}

The importance of grammar in Indian classical culture cannot be overestimated. The extent to which it has exerted a determining influence on the Indian sciences is less easy to estimate, and exaggerated assessments have become all too common. The

\footnotetext{
${ }^{26} \mathrm{Cp}$. Bhatta, 1994; Edgerton, 1929.

${ }^{27}$ See the description of the contents of his chapter on verbal testimony in Potter and Bhattacharyya, 1992: 239-312, which coincides in part with Vidyabhusana, 1920.

${ }^{28}$ Cp. Vkp 3.8.40 ff.; tr. Bandini, 1980.

${ }^{29}$ Cp. Joshi, 1993; 1995 (esp. p. 22 ff.).
} 
search for the fundamental nature of the Indian sciences, or of Indian thought in general, as being based on the supposedly all-important influence of grammar, is not likely to lead beyond more or less attractive slogans. This does not mean that there has not been intensive interaction between grammar and the other sciences, nor [172] that this interaction has not left its traces. Bringing those traces to light will require continued detailed philological research.

\section{Bibliography}

Bandini, Giovanni (1980): Die Erörterung der Wirksamkeit. Bhartrharis Kriyāsamuddeśa und Helārājas Prakāśa zum ersten Male aus dem Sanskrit übersetzt, mit einer Einführung und einem Glossar versehen. Wiesbaden: Franz Steiner. (BSAI. 61.)

Bhatta, V.P. (1994): Mandana Miśra's Distinction of the Activity: Bhāvanāviveka. With introduction, English translation with notes, and Sanskrit text. Delhi: Eastern Book Linkers.

Bhattacharya, Kamaleswar (1995): "Back to Nāgārjuna and grammar." ALB 59, 178-189.

Bronkhorst, Johannes (1980): "The role of meanings in Pānini's grammar." IL 40(3), 1979 [1980], 146-157.

Bronkhorst, Johannes (1981): "The orthoepic diaskeuasis of the Rgveda and the date of Pānini.". IIJ 23, 83-95.

Bronkhorst, Johannes (1981a): "Nirukta and Aș̣āāhyāyī: their shared presuppositions." IIJ $23,1-14$.

Bronkhorst, Johannes (1984): "Nirukta, Unādi Sūtra, and Aṣtādhyāyī." IIJ 27, 1-15.

Bronkhorst, Johannes (1987): "The Mahābhāssya and the development of Indian philosophy." Three Problems pertaining to the Mahābhāsya. Poona: Bhandarkar Oriental Research Institute. Pp. 43-71.

Bronkhorst, Johannes (1991): "Pānini and the Veda reconsidered." Pāninian Studies. Professor S. D. Joshi Felicitation Volume. Ed. Madhav M. Deshpande and Saroja Bhate. Ann Arbor: Center for South and Southeast Asian Studies, University of Michigan, nr. 37. Pp. 75-121.

Bronkhorst, Johannes (1991a): "Studies on Bhartrhari, 3: Bhartrhari on sphota and universals." AS 45(1), 5-18.

Bronkhorst, Johannes (1992): "Quelques axiomes du Vaiśeșika." Les Cahiers de Philosophie 14 ("L'orient de la pensée: philosophies en Inde"), 95-110.

Bronkhorst, Johannes (1992a): "Études sur Bhartrhari, 4: L'absolu dans le Vākyapadīya et son lien avec le Madhyamaka." AS 46(1), 56-80.

Bronkhorst, Johannes (1996): "Sanskrit and reality: the Buddhist contribution." Ideology and Status of Sanskrit: Contributions to the history of the Sanskrit language. Ed. Jan E.M. Houben. Leiden etc.: E.J. Brill. (Brill's Indological Library, 13.) Pp. 109-135.

Bronkhorst, Johannes (1996a): "The correspondence principle and its impact on Indian philosophy." Indo-Shisōshi Kenkyū / Studies in the History of Indian Thought (Kyoto) 8, 1996, 1-19.

Bronkhorst, Johannes (1996b): "Studies on Bhartrhari, 7: Grammar as the door to liberation." ABORI 76 (1995 [1996]), 97-106.

Bronkhorst, Johannes (forthcoming): Langage et réalité: sur un épisode de la pensée indienne.

Bronkhorst, Johannes (forthcoming a): "Les éléments linguistiques porteurs de sens dans la tradition grammaticale du sanscrit." Actes du Colloque annuel de la Société 
d'Histoire et d'Épistémologie des Sciences du Langage, à l'École Normale Supérieure, Paris 1995 ("Grammaires indiennes: théories et histoire")

Brough, John (1951): "Theories of general linguistics in the Sanskrit grammarians." (TPS 1951, pp. 27-46) = Staal, 1972: 402-414.

Cardona, George (1976): Pānini. A survey of research. Reprint: Motilal Banarsidass, Delhi etc. 1980.

Coward, Harold G., and Kunjunni Raja, K. (1990): "Śābdabodha." Encyclopedia of Indian Philosophies, V: The Philosophy of the Grammarians. Ed. Harold G. Coward and K. Kunjunni Raja. Delhi etc.: Motilal Banrsidass. Pp. 93-97.

Edgerton, Franklin (1929): The Mìmānssā Nyāya Prakāśa or Āpadevī: A treatise on the Mìmānisā system by Āpadeva. Translated into English, with an introduction, transliterated Sanskrit text, and glossarial index. Reprint: Sri Satguru Publications, Delhi. 1986.

Falk, Harry (1993): Schrift im alten Indien. Ein Forschungsbericht mit Anmerkungen. Tübingen: Gunter Narr. (ScriptOralia 56.)

Filliozat, Pierre-Sylvain (1988): Grammaire sanskrite pâninéenne. Paris: Picard.

Filliozat, Pierre-Sylvain (1995): "Sanskrit linguistics and mathematics in ancient India." Indian Horizons 44(4), 39-50.

Frauwallner, Erich (1938): "Bhāvanā und Vidhih bei Maṇụanamiśra." (WZKM 45, 212252) $=$ KISchr pp. 161-201.

Hinüber, Oskar v. (1989): Der Beginn der Schrift und frühe Schriftlichkeit in Indien. Stuttgart: Franz Steiner. (AAWL Jhrg. 1989, Nr. 11.)

Ingalls, Daniel H.H. (1954): "The comparison of Indian and Western philosophy." JORM 22, 1-11.

Joshi, Shivaram Dattatray (1993): "Kaunda Bhatta on the meaning of Sanskrit verbs (1)." Nagoya Studies in Indian Cülture and Buddhism, Sambhāsā 14, 1-39.

Joshi, Shivaram Dattatray (1995): "Kaunda Bhatta on the meaning of Sanskrit verbs (2)." Nagoya Studies in Indian Culture añd Buddhism, Sambhāạāā 16, 1-66.

Matilal, Bimal Krishna (1971): Epistemology, Logic and Grammar in Indian Philosophical Analysis. The Hague - Paris: Mouton.

Matilal, Bimal Krishna (1988): "Śābdabodha and the problem of knowledgerepresentation in Sanskrit." JIP 16, 107-122.

Matilal, Bimal Krishna (1990): The Word and the World. India's Contribution to the study of language. Delhi: Oxford University Press.

Potter, Karl H., and Bhattacharyya, Sibajiban (ed.)(1992): Encyclopedia of Indian Philosophies, VI: Indian Philosophical Analysis. Nyāya-Vaiśeșika from Gañgeśa to Raghunātha Siromani. Princeton, New Jersey: Princeton University Press.

Rao, Veluri Subba (1969): The Philosophy of a Sentence and its Parts. New Delhi: Munshiram Manoharlal.

Renou, Louis (1942): "Les connexions entre le rituel et la grammaire en sanskrit." JA 233 (1941-42), 105-165. (= Staal, 1972: 435-469.)

Renou, Louis (1953): "L'érudition." L'Inde classique II. Ed. Louis Renou and Jean Filliozat. Reprint, Paris: Adrien-Maisonneuve. 1985. Pp. 85-137.

Renou, Louis (1963): "Sur le genre du sūtra dans la littérature sanscrite." JA 251, 165216.

Ruegg, D. Seyfort (1978): "Mathematical and linguistic models in Indian thought: the case of zero and súnyatā." WZKS 22, 171-181.

Scharfe, Hartmut (1977): Grammatical Literature. Wiesbaden: Otto Harrassowitz. (HIL vol. V, fasc. 2.)

Staal, Frits (1960): Review of Contributions à l'histoire de la philosophie linguistique indienne by D.S. Ruegg. PEW 10, 53-57.

Staal, Frits (1963): "Euclides and Pānini: twee methodische richtlijnen voor de filosofie." (Amsterdam: Polak \& Van Gennep) = Staal, 1986: 77-115.

Staal, Frits (1965): "Euclid and Pānini." (PEW 15, 99-116) = Staal, 1988: 143-160.

Staal, J.F. (ed.)(1972): A Reader on the Sanskrit Grammarians. Cambridge, Massachusetts, and London, England: MIT Press. 
Staal, Frits (1982): The Science of Ritual. Poona: Bhandarkar Oriental Research Institute. (Post-graduate and Research Department Series No. 15.)

Staal, Frits (1986): Over zin en onzin in filosofie, religie en wetenschap. Amsterdam: Meulenhoff Informatief.

Staal, Frits (1988): Universals. Studies in Indian Logic and Linguistics. University of Chicago Press.

Staal, Frits (1989): Rules Without Meaning. Ritual, mantras and the human sciences. New York: Peter Lang. 1989. xix + 490 pp. (Toronto Studies in Religion, 4.)

Thieme, Paul (1935): "Zur Datierung des Pānini." ZDMG 89, *21* $-* 24 *=$ K1Schr (1971), pp. 528-531.

Thieme, Paul (1982): "Meaning and form of the 'grammar' of Pānini." StII 8/9, 1-34 = KlSchr II (1995), pp. 1170-1201.

Torella, Raffaele (1987): "Examples of the influence of Sanskrit grammar on Indian Philosophy." EW 37, 151-164.

Vidyabhusana, Satis Chandra (1920): A History of Indian Logic. Reprint: Motilal Banarsidass, Delhi etc., 1978.

Abbreviations:

AAWL Abhandlungen der Akademie der Wissenschaften und der Literatur,

ABORI $\quad$ Mainz, Geistes- und Sozialwissenschaftliche Klasse

ALB The Brahmavidyā, Adyar Library Bulletin, Madras

AS Asiatische Studien, Études Asiatiques, Bern

ASS Ānandāśrama Sanskrit Series, Poona

BSAI Beiträge zur Südasienforschung, Südasien-Institut, Universität

Heidelberg

EW East and West, Roma

HIL A History of Indian Literature, ed. J. Gonda, Wiesbaden $1973 \mathrm{ff}$.

IIJ Indo-Iranian Journal, Den Haag, Dordrecht

IL Indian Linguistics, Pune

JA Journal Asiatique, Paris

JIP Journal of Indian Philosophy, Dordrecht

JORM Journal of Oriental Research, Madras

KISchr Kleine Schriften (Serie der Glasenapp-Stiftung), Wiesbaden, Stuttgart

MīS Mīmāmsā Sūtra, ASS vol. 97.

PEW Philosophy East and West

StII Studien zur Indologie und Iranistik

TPS Transactions of the Philological Society, Oxford

Vkp Bhartrhari, Vākyapadīya, ed. W. Rau, Wiesbaden 1977

WZKM Wiener Zeitschrift für die Kunde des Morgenlandes, Wien

WZKS Wiener Zeitschrift für die Kunde Südasiens, Wien

ZDMG Zeitschrift der Deutschen Morgenländischen Gesellschaft, Leipzig, later Wiesbaden 